\title{
The Educational Evolution in Germany, the study case: Primary Education (Grundschule)
}

\section{La Evolución Educativa en Alemania, el caso de estudio: Educación Primaria (Grundschule)}

\author{
Ali Ashrafi \\ Department of Teaching English, University of Applied Science and Technology, Tehran, Iran.
}

ORCID: https://orcid.org/0000-0002-3140-8100

Received 09-08-20 Revised 10-10-20

*Correspondence

Email: Ali.Ashrafi.Sarvak11@gmail.com

(C) Universidad San Ignacio de Loyola, Vicerrectorado de Investigación, 2021 $\mathrm{nd} / 4.0 /)$. 


\section{Summary}

Primary education levels are called primary education, compulsory education, and public education. Nowadays, new research has shown that primary education plays an important role in the reduction of poverty and the realization of economic and social development programs. Therefore, the necessity of this research is to study the evolution of primary education and its influencing factors in Germany. Also, the primary organization and how to select the teacher education and primary curriculum will be examined. In this research, the research method is descriptive. The results showed that in the primary period of the German education system, politics, ideology, and ideas of educators have played an important role in the development of education and, as such, in primary education. As can be observed in the Weimar Republic, education was influenced by the political theories of democracy, and then, during the Nazis, was influenced by the ideology of Nazism and the superiority of the Nazi German race; during World War II and thereafter Was influenced by communist ideology and Marxist thoughts. In the new era, there have also been major reforms to eliminate the influence of these new educators' ideologies and educational ideas.

Key words: Primary education system, Primary education and training organization, Primary education Germany.

\section{Resumen}

Los niveles de educación primaria se denominan educación primaria, educación obligatoria y educación pública. Hoy en día, una nueva investigación ha demostrado que la educación primaria juega un papel importante en la reducción de la pobreza y la realización de programas de desarrollo económico y social. Por lo tanto, la necesidad de esta investigación es estudiar la evolución de la educación primaria y sus factores influyentes en Alemania. Además, se examinará la organización primaria y cómo seleccionar la formación docente y el plan de estudios primario. En esta investigación, el método de investigación es descriptivo. Los resultados mostraron que en el período primario del sistema educativo alemán, la política, la ideología y las ideas de los educadores han jugado un papel importante en el desarrollo de la educación y, como tal, en la educación primaria. Como se puede observar en la República de Weimar, la educación fue influenciada por las teorías políticas de la democracia, y luego, durante los nazis, fue influenciada por la ideología del nazismo y la superioridad de la raza nazi alemana; durante la Segunda Guerra Mundial y posteriormente fue influenciado por la ideología comunista y los pensamientos marxistas. En la nueva era, también ha habido reformas importantes para eliminar la influencia de las ideologías e ideas educativas de estos nuevos educadores.

Palabras clave: Sistema de educación primaria, Organización de educación y formación primaria, Educación primaria Alemania.

\section{Introduction}

In today's world, the issue of how to manage education is very important. The education of each country is the main organization responsible for the preservation and concentration of values, the education of the future generation of society and ultimately, the excellence of human. Also, the most important stage in all worldwide education systems is the primary period because the personality and development of children are formed during this period more than any period. A review of current experiences shows that each country has adopted principles for policymaking and reforming change. For example, the German education system was changed in Germany in 1949 by adopting the basic law of education, social, political and cultural foundations in Germany. This law explicitly emphasizes the right of all German children to have public education on their talents and abilities (Beutner el al, 2017). 
The most important purpose in German primary education is to create an area for students' creativity. In primary schools, in addition to reading and writing mother tongue, other material including social sciences, history, geology, biology, physics and chemistry, music, art education, manual work of mathematics, physical education and religious sciences (such as the Bible of the Bible). All curriculums are compulsory (Foraker, 2008). Weekly hours for lessons depend on the school year and usually range from 20 to 30 hours. In this research, the evolution of primary education and the factors that affect it, the way of selecting and educating the teacher and the primary curriculum and how it is implemented in the country are investigated.

\section{Literature Review}

Germany is located in the central European countries and the northern hemisphere. The country's total area is 357,000 square kilometers. Germany is the most popular member of the European Union, which is based on 2003 statistics. Also, Berlin is the capital of the state of Berlin, which has great historical, cultural and economic significance. In the early 1970s, school curricula were reformed throughout Germany, especially at primary and secondary levels. The first project in science and mathematics, adapted from the experience of the Americans, was implemented. In 1937, the reform of the primary school curriculum was issued by the German government. The Nazi party educators from primary schools (Grind Schule) were named as the National School. The course at this school was four years from the age of 6 years old. Also, public education in Germany is based on two principles of being compulsory and free. These pieces of the training start at age 6 and continue until age 18 (Engle and Hurrelman, 1998). Academic degrees in Germany are divided into four stages: pre-school education, primary education, secondary education, and higher education. Rubitell and others (1993) have shown that the quality of teacher education and the quality of teaching depend heavily on educational resources, especially the curriculum. And the importance of the curriculum in the context of the variable ruling among the educational systems of the countries and the factor of educational returns. Therefore, reconstruction of the educational system is carried out through reforming curriculum and teaching methods(Rubitell, 1993). Garrido (1989), in response to the responses from countries to the International Bureau of Education's questionnaires at the thirty-ninth education conference, conducted extensive studies on education. According to Ed, most countries have a centralized system that tends to focus on decentralization. Also, the period of the initial period states that it varies from age 3 to 9, but these opposing views will come closer to each other, now the average is 6 years. To strengthen primary education, it is necessary to increase the continuity of practice between pre-primary and primary schools. García Garrido, J.L. (1996), in the primary education book on the eve of the twenty-first century, addresses both the world's primary education at the end of the 20th century and the way it will be at the beginning of the 21 st century. In this paper, he has achieved the following results(García Garrido, 1996). The nationalization process of primary education has been rising in the twentieth century and has grown throughout the world over the past decades. Concerning the government and the early-stage organization in the second half of the 20th century, it may have been the opposite of the desire to reform each country's policy. The allocation of incremental funding to primary education in recent years has been one of the largest education budget items in public budgets and is likely to remain. Foreign economic assistance is critical to the quantitative and qualitative development of primary education in developing countries. In the future, it may depend greatly on the flow of the global economy and the climate of seizure and cooperation between countries(Aghazadeh, 2004).

\section{Methodology}

In this study, the research method is descriptive and researcher in this method report without interference and mentally inferring. In other words, this research describes its current systematic approach and examines the features and definitions of it and, if necessary, examines the 
relationship between variables. The purpose of the choice of Germany is that the German educational system in the creation of the century civilization and culture. The method of collecting information and data is based on using the Internet, thesis, and articles in journals and visiting the cultural sections of the German Embassy.

\section{Results and Discussion}

The evolution of the primary Germanic period is established in the Weimar Republic, which was the basis of the German primary schools at that time. Education was influenced by the educational opinion that inspired the political theories of democracy. During the Nazi rule, education was a tool for Nazi propaganda and the German race, so that history and biology courses in primary schools would propagate it. After the Second World War, work-based schools in eastern Germany were founded following the Marxist axis-based production ideology of ten-year-old workingclass schools. Following the unification of Germany in 1990, a fundamental reform plan for the eastern German education system was approved by the Federal Assembly. Under this plan, extensive measures were taken to change the eastern German system based on the foundations of communism, and educational work was conducted in a centralized manner. Currently, educational reforms are being carried out according to the results of educational research in Germany, including the establishment of full-time schools based on research conducted by educational experts in Germany and expanding. Also, in the primary period of the German education system, politics, ideology, and ideas of educators have played an important role in the development of education and as primary education. As can be seen in the Weimar Republic; education is affected by political theories, and after that during the Nazis, it was influenced by the ideology of Nazism and superior nasal race Germany; During World War II and afterward, it was influenced by communist ideology and Marxist thoughts. In the new era, fundamental reforms to eliminate the effects of these ideologies and educational ideas.

\subsection{Primary education in Germany}

Public education in Germany is based on two principles of being compulsory and free. These pieces of the training start at age 6 and continue until age 18. In 1949, with the adoption of the basic law of education, the social, political and cultural foundations of Germany were subject to changes. The law explicitly emphasizes the right of all German children to have universal education based on their talents and abilities.

In article 7 of this law states: Central and local governments are required to provide facilities and facilities for all segments of the German industrial community so that children and young people can enjoy the benefits of free and public education and respond to the needs of the new age in the field of social and labor market and specialty activity (SEP, 1989). In some states of Germany, the first and second classes are presented in an integrated manner. So that students can progress to these two classes within one to three years.

The period of study at this stage lasts 4 years, and this period is only 6 years in the provinces of Berlin and Brandenburg. In the first two years of primary education, students of a class are taught only by a teacher, but from the third year, teachers are specialized in teaching lessons. Primary education is based on entertainment. In the first two classes, the student performance evaluation system is conducted through a qualitative report on the student's educational status. At an early stage, students learn to read, write, and count in the early stages. But gradually they teach children lessons like German language, mathematics, science, art, music, and sports(.Education system Germany, 2015)

Although the German state has a secular government, religious education is considered a school course in most states. Students who do not have good grades in primary schools can study from the fifth to ninth grade at Haupt scholar schools. In these schools, it is more instructive than Guimenaes and Realschule schools and is being taught more by way of examples and practical 
exercises rather than dealing with theoretical and non-mental content. Students will be able to study at the technical and vocational schools after completion of their education in these schools. The lessons in Realschule schools are more difficult and more comprehensive than Haupt scholar schools.

\subsubsection{Historical evolution}

The German Primary School rules come back to 1920 in Germany, which was founded in accordance with Section 146 of the Weimar Republic Law, which Grind Schule was established as an institution for the education of all German children, which was founded in accordance with Section 146 of the Weimar Republic Law, which Grind Schule was established as an institution for the education of all German children. By 1920, there were separate educational institutions along with primary schools. They prepared the children for middle and high schools, which were dismantled by the German law of the Reich. The complete separation of students based on the class or social status, which until now was widely used, was eliminated, and all children could learn together in the first years of school. Establishing a republic in this period caused the movement of active learning schools. The ethical values of socialism and political democracy led to the awareness of the leading educators who participated in the meetings of the Democratic and Social-Democratic Party of Germany.

Totally, with the goal of child development, they were able to develop the principles and methods of education. They argued that in school, active learning would be more conducive to ethical education and the citizenship of children than traditional methods, because it would give children more opportunity to work together, tolerate, and other citizenship traits. To develop a sense of responsibility in fulfilling the task of students for good and proper work, the classroom teacher turned the classroom into an active school in learning to a working community that was mutually beneficial in terms of action and practice. Group work and mutual learning have been more current in the classes.

Fixed benches were replaced with movable benches and cubicles, and the children shared their lessons and their work. Otto Ernner and Martin Wies, who taught active learning schools at the University of Leipzig and Dresden, saw how teaching methods and learning process would force forces to lead citizenship in free children and prepare them for active responsibility and selfreliance. Teachers in the activity-oriented schools eliminated physical punishment and supported friendships with students.

The principles adopted in 1921 for primary education in Germany are as follows:

The first principle is a Compilation teaching that coordinates the various subjects and establishes a close relationship between them as much as possible, instead of teaching separate subjects. The second principle is knowledge, environment, and home. In other words, there must be a closer relationship between schoolwork and outside school experiences and the third principle is the principle of activity.

\subsection{Primary Education and Training Organization in Germany}

The management and regulation of the German education system are initially in the state's area of responsibility. Ministers of Education and Cultural Affairs and Science in the state are the highest authority in each state's educational affairs. Supervising the school system (general and vocational education); planning and organizing the entire school system within the authority of ministers of education and cultural affairs and school management. The state is not solely responsible for organizing the school structure and determining the content of the courses and teaching objectives.

The first level school administration is for the ministers of education and cultural affairs, at the next level, the regional rulers and, at a lower level, the local governors of the school administration. In Germany, these are federal education ministries, along with city administrators and school administrators who manage schools, and educational programs and instructions have 
plenty of flexibility. The characteristics of the German educational system are summarized in table 1 .

\begin{tabular}{|c|c|c|}
\hline 1 & $\begin{array}{c}\text { The development of primary } \\
\text { school education }\end{array}$ & $\begin{array}{ll} & \text { In 4 steps: } \\
\text { 1- } & \text { Weimar Republic } \\
\text { 2- } & \text { Nazi era } \\
\text { 3- } & \text { After World War II } \\
\text { 4- } & \text { After the unification } \\
& \text { of Germany }\end{array}$ \\
\hline 2 & $\begin{array}{l}\text { The organization of primary } \\
\text { education }\end{array}$ & Non-centralized \\
\hline 3 & $\begin{array}{l}\text { Curriculum and implement } \\
\text { primary education }\end{array}$ & Non-centered and threaded \\
\hline 4 & $\begin{array}{l}\text { development of primary } \\
\text { school education path }\end{array}$ & $\begin{array}{l}\text { Following the unification of } \\
\text { Germany in 1990, the } \\
\text { fundamental reform of the } \\
\text { educational system was } \\
\text { approved by the Federal } \\
\text { Assembly. }\end{array}$ \\
\hline
\end{tabular}

\section{Conclusion}

The educational system of each country is the main organization that is responsible for the preservation and consolidation of values, the education of the future generation of society and, ultimately, the excellence of human beings. This movement starts in the primary period. It can be concluded that education in each country and, as such, primary education has undergone tremendous changes from the beginning to the present. But in each country, the process of further development has focused on one issue. In the primary period of the German education system, politics, ideology, and ideas of educators have played an important role in the transformation of education and, as such, in primary education. As it is seen in the Weimar Republic; education influenced by political theories and after that, during the Nazis, it was influenced by the ideology of Nazism and superior nasal race Germany; during the Second World War and afterward it was influenced by Communist ideology and Marxist thoughts. In the new era, fundamental reforms to eliminate the effects of these ideologies and educational ideas of new instructors. In Germany, the federal education ministries, along with city administrators and school administrators manage schools, and educational programs and instructions have plenty of flexibility.

\section{References}

1. Beutner, Mark, and Rasmus Pechuel. "Education and educational policy in Germany. A focus on core developments since 1944." Italian Journal of Sociology of Education 9, no. 2 (2017).

2. Foraker, W. C. "The educational structure of the German school system." Retrieved November 8 (2006): 2008.

3. Bonn. Lennestr; (1998) International conference Education, Genera TheEducation System in the Federal Republic of Germany.

4. Engle and Hurrelman (1998), Educational Careers of Teacher in Germany, T; 2004 odt, Hessen. 
5. Rubitell and others (1993), Comparative analysis of the traditional and the integrated curricula in Ghanaian secondary schools,School of Education, Murdoch University.

6. García Garrido, J.L. (1996): Diccionario Europeo de la Educación. Madrid: Dykinson.

7. Aghazadeh, Ahmad (2004) Education of Advanced Industrial Countries, Tehran, Ravan Publishing House.

8. Education system Germany ,Nuffic, 2nd edition February 2011,version 2, January 2015 2 . 